Indian J Anim Health (2021), 60(2): 242-249

DOI: https://doi.org/10.36062/ijah.2021.05221

\title{
Influence of dietary zinc and manganese chelate on productive and reproductive performance of layer chicken
}

\author{
S. Mondal ${ }^{1}$, B. Roy ${ }^{1}$, P. Biswas ${ }^{1}$, T. Rana ${ }^{2}$, I. Kar $^{3 *}$ and S. Das ${ }^{4 *}$ \\ ${ }^{1}$ Department of Animal Nutrition, West Bengal University of Animal and Fishery Sciences, Kolkata- \\ 700 037, West Bengal, India; ${ }^{2}$ Department of Veterinary Clinical Complex, West Bengal University \\ of Animal and Fishery Sciences, Kolkata-700 037, West Bengal, India; ${ }^{3}$ Department of Avian Science, \\ West Bengal University of Animal and Fishery Sciences, Kolkata-700 037, West Bengal, India; \\ ${ }^{4}$ Department of Fish Nutrition, West Bengal University of Animal and Fishery Sciences, Kolkata- \\ 700 094, West Bengal, India
}

\begin{abstract}
Zinc (Zn) and Manganese (Mn) are two essential trace minerals for layer chickens. Present study was conducted to assess the effect of different sources of $\mathrm{Zn}$ and $\mathrm{Mn}$ on general performance, egg quality and reproductive performance of layers. One hundred and twenty RIR pullets (108 hens and 12 cocks) were randomly distributed in four experimental groups. Each group consisted of 30 birds in three replicates, each having 10 birds ( 9 hens and 1 cock). The first group was supplied with traditional mineral mixture as per requirement of BIS (1992) and considered as control (CTR). Other three treatment groups were supplied with same mineral mixture with high level (50\%) of Mn and Zn (TMZ), amino acid chelate ( $\mathrm{Zn}$ and $\mathrm{Mn}$ ) as per requirement (TIC) and organic chelate of $\mathrm{Zn}$ and $\mathrm{Mn}$ (TOC) half of the requirement respectively. First laying age was significantly $(P<0.01)$ lower in case of both the chelate supplemented groups. Feed efficiency $(P<0.01)$, weight of eggs $(P<0.01)$, shape index $(P<0.01)$, albumen index $(P<0.01)$, yolk index $(P<0.01)$, shell thickness $(\mathbf{P}<0.05)$ and Haugh unit $(\mathbf{P}<0.01)$ were significantly higher in both the chelated $\mathrm{Zn}$ and Mn supplemented groups. However, membrane thickness, shell, yolk and albumen percentage values were not significantly varied among groups. No significant difference was found in fertility percentage of eggs among the groups but hatchability was improved significantly $(\mathbf{P}<\mathbf{0 . 0 5})$ in organic source chelate supplementation. It is concluded that supplementation of chelated $\mathrm{Zn}$ and Mn may improve overall performance, egg quality and hatchability in RIR layer chickens.
\end{abstract}

Key words: Chelates, Egg production, Layer chicken, Manganese, Zinc

\section{INTRODUCTION}

Mineral is one of the most essential nutrients needed for various metabolic and body functions to maintain optimum growth and egg production in layer chicken. In addition to marco minerals like $\mathrm{Ca}$ and $\mathrm{P}$ along with vitamin $\mathrm{D}_{3}$, trace elements like $\mathrm{Zn}$ and $\mathrm{Mn}$ also have a major role in affecting the eggshell quality (Swiatkiewicz and Koreleski, 2008). Zn and $\mathrm{Mn}$ also play a vital role in various metabolic, biochemical and enzymatic pathways leading to better growth, egg production and feed efficiency. They have a very vital role to play in the mechanism of nutrient circulation in the animal. In case of laying hen enzyme carbonic anhydrase from the shell gland of the oviduct is essential for eggshell formation and calcification of bone from carbonate ions (Leeson and Summers, 2009). Zinc is a major component of carbonic anhydrase. The significant role $\mathrm{Zn}$ plays is in reproduction, development of blood cells, immune system function and bone development (Hafeez, 2015). Deficiency of Zn may cause a drop in egg production and poor eggshell quality (Favero et al., 2013). Mn is also a vital trace element having an essential role in growth, normal brain function, reproduction, amino acid metabolism, biosynthetic processes, physiological function and various enzymatic systems (Yildiz et al., 2011). In poultry, $\mathrm{Mn}$ is also required for bone plate growth and bone cartilage formation (Zamani et al., 2005). Reduced egg production

"Corresponding Authors: E mail: indrajitkar78@gmail.com, drsridas@gmail.com 
and eggshell deformities are observed in $\mathrm{Mn}$ deficiency in laying hen (Mabe et al., 2003). The requirements for $\mathrm{Zn}$ and $\mathrm{Mn}$ may not be fulfilled by the concentrations available in the regular feed and hence require supplementation to ensure adequate intake of minerals. Again bioavailability of minerals is related to the chemical form of the supplement along with other factors (Dobrzanski et al., 2003). The use of various sources of trace minerals, different processing forms, and interaction among the minerals can influence its bioavailability. The researchers are trying to bind the minerals with amino acids, organic acids and other binders or chelators to increase the absorption of minerals and thereby making them more bioavailable (Gheisari et al., 2011). A balance between dietary mineral supplementation and their different forms is important for better bioavailability. Few studies reported that substituting inorganic $\mathrm{Zn}$ and $\mathrm{Mn}$ with organic proteinates (Bioplex $\mathrm{Zn}$ and Bioplex $\mathrm{Mn}$ ) improved laying performance, egg weight and egg mass in poultry (Siske et al., 2000). A significant improvement in uniformity of the laying curve was also observed. In view of the above facts, to compare the efficacy of various forms and levels of $\mathrm{Zn}$ and $\mathrm{Mn}$ supplement in the diet of layer chicken, the present study was undertaken to evaluate the effect on overall performance, egg quality, fertility and hatchability of eggs in layer chickens.

\section{MATERIALS AND METHODS}

One hundred and twenty, 16 week old pullets (108 hens and 12 cocks) belonging to the Rhode Island Red (RIR) strain were brought from Government Poultry Farm and were randomly assigned to four experimental groups - one control group and three treatment groups with three replicates, with ten birds ( 9 hens and 1 cock) in each replicate. Each group was housed separately allowing $5 \mathrm{ft}$ x $6 \mathrm{ft}$ deep litter floor partitioned by iron net within a layer house. The firs group was supplied with the traditional mineral mixture as per the requirement of BIS (1992) and considered as control (CTR). The other three treatment groups were provided with the same mineral mixture with high level (50\%) of Mn and Zn (TMZ), amino acid chelate ( $\mathrm{Zn}$ and $\mathrm{Mn}$ ) as per requirement (TIC) and organic chelate of $\mathrm{Zn}$ and $\mathrm{Mn}$ (TOC) half of the requirement respectively. Birds were fed the grower (up to $20^{\text {th }}$ week of age) and layer $\left(21^{\text {st }}\right.$ to $42^{\text {nd }}$ week of age) ration (Table 1). Diets were prepared to meet the nutrient requirements as per BIS (1992) except $\mathrm{Zn}$ and $\mathrm{Mn}$ in particular treatment concerned. Birds were exposed to 18 hours of light and 6 hours of darkness throughout the experiment. All the birds were fed accurately weighed feed material twice a day, and the leftover feed, if any, was collected in the next day morning to determine the residue and actual consumption of feed per day per bird. All the birds were offered water ad libitum in clean water troughs every day throughout the experimental period.

Diets for both the grower and layer birds were prepared by adding trace mineral mixture to the respective group. The trace minerals were supplemented as per the requirement of BIS (1992) without considering the availability of trace minerals from the feed. The composition of trace mineral mixture of control diet for both grower and layer birds are given in Table 2. The diets of the TMZ group contained $50 \%$ more $\mathrm{Zn}$ and $\mathrm{Mn}$ than the requirement as per the BIS standard (1992). In the rest two groups, $\mathrm{Zn}$ and $\mathrm{Mn}$ were supplemented from commercially procured amino chelate and organic chelate $\left(\right.$ Alltech ${ }^{\mathrm{R}}$ ) respectively. The procedure adopted for extracting trace minerals in feed was done by wet oxidation as per the method suggested by AOAC (1970) for estimation of $\mathrm{Zn}$ and $\mathrm{Mn}$ with the help of Atomic Absorption Spectrophotometer (Perkin Elmer Analyst 100). Productive and reproductive performances of various experimental groups were calculated for the period of $22 \mathrm{wks}\left(21^{\text {st }}\right.$ to $42^{\text {nd }}$ wk of age). Twelve eggs were randomly collected per treatment group for egg quality measurement. Eggs were collected mainly in the morning time daily and marked. They were kept in a dried, clean container with the dust of rice bran at room temperature. To evaluate the 
Table 1. Ingredient and nutrient composition of basal diet for grower and layer birds

\begin{tabular}{lll}
\hline \multicolumn{1}{c}{ Particulars } & kg/100 kg feed & \\
\hline Ingredient composition & Grower & Layer \\
\hline MAIZE & 39.000 & 48.680 \\
DORB & 39.780 & 16.920 \\
SOYABEAN MEAL & 10.320 & 17.510 \\
TILCAKE & 2.870 & 5.420 \\
FISH MEAL & 3.740 & 2.670 \\
LIMESTONE POWDER & 1.000 & 1.000 \\
DICALCIUM PHOSPHATE & 1.000 & 1.000 \\
OYSTER SHELL & 2.000 & 6.000 \\
NICOMIX* & 0.025 & 0.025 \\
DL-METHIONINE & 0.025 & 0.050 \\
CHOLINE CHLORIDE & 0.164 & 0.150 \\
SOYABEAN OIL & - & 0.500 \\
\hline NUTRIENT COMPOSITION & GROWER & LAYER \\
CP $(\%)^{1}$ & 16.20 & 18.23 \\
CF $(\%)^{1}$ & 7.52 & 4.99 \\
EE $(\%)^{1}$ & 1.51 & 2.50 \\
NFE $(\%)^{2}$ & 65.95 & 62.82 \\
TOTALASH $(\%)^{1}$ & 8.82 & 11.46 \\
ME $($ KCAL/KG) & 2552.36 & 2622.23 \\
CA $(\%)^{1}$ & 1.89 & 3.371 \\
AVAILABLE P $(\%)^{2}$ & 0.68 & 0.57 \\
ZINC $($ MG/KG) & 40.65 & 35.74 \\
MANGANESE $(M G / K G)$ & 47.98 & 29.03 \\
\hline
\end{tabular}

*Each gram of Nicomix contained Vitamin A- 40,000IU, Vitamin D3- 6,000 IU, Vitamin B1- 3.2mg, Vitamin B220mg, Vitamin B6- 6.4mg, Vitamin B12- $82 \mathrm{mcg}$, Niacin- 48mg, Calcium pantothenate- 32mg, Vitamin K- 4mg, Vitamin E- 32mg and Folic acid- 3.2mg; ${ }^{1}$ Estimated values ; ${ }^{2}$ Calculated values

Table 2. Composition of trace mineral mixtures used in different groups

\begin{tabular}{|c|c|c|c|c|c|c|c|c|}
\hline \multirow{3}{*}{ Particulars } & \multicolumn{8}{|c|}{ Quantity (g/100kg feed) } \\
\hline & \multicolumn{2}{|c|}{ CTR } & \multicolumn{2}{|c|}{ TMZ } & \multicolumn{2}{|c|}{ TIC } & \multicolumn{2}{|c|}{ TOC } \\
\hline & Grower & Layer & Grower & Layer & Grower & Layer & Grower & Layer \\
\hline $\begin{array}{l}\text { Ferrous sulphate }\left(\mathrm{FeSO}_{4},\right. \\
\left.7 \mathrm{H}_{2} \mathrm{O}\right)\end{array}$ & 45.00 & 37.50 & 45.00 & 37.50 & 45.00 & 37.50 & 45.00 & 37.50 \\
\hline $\begin{array}{l}\text { Copper sulphate }\left(\mathrm{CuSO}_{4} \text {, }\right. \\
\left.5 \mathrm{H}_{2} \mathrm{O}\right)\end{array}$ & 3.60 & 3.60 & 3.60 & 3.60 & 3.60 & 3.60 & 3.60 & 3.60 \\
\hline Potassium iodide (KI) & 0.15 & 0.15 & 0.15 & 0.15 & 0.15 & 0.15 & 0.15 & 0.15 \\
\hline Sodium selenite $\left(\mathrm{Na}_{2} \mathrm{SeO}_{3}\right)$ & 0.20 & 0.20 & 0.20 & 0.20 & 0.20 & 0.20 & 0.20 & 0.20 \\
\hline $\begin{array}{l}\text { Zinc sulphate }\left(\mathrm{ZnSO}_{4}\right. \\
\left.7 \mathrm{H}_{2} \mathrm{O}\right)\end{array}$ & 12.50 & 18.75 & 18.75 & 28.13 & - & - & - & - \\
\hline $\begin{array}{l}\text { Manganese sulphate } \\
\left(\mathrm{MnSO}_{4}, \mathrm{H}_{2} \mathrm{O}\right)\end{array}$ & 13.90 & 15.30 & 20.85 & 22.94 & - & - & - & \\
\hline Amino chelate of zinc & - & - & - & - & 31.15 & 46.73 & - & - \\
\hline $\begin{array}{l}\text { Amino chelate of } \\
\text { manganese }\end{array}$ & - & - & - & - & 35.08 & 38.06 & - & - \\
\hline Bioplex Zinc & - & - & - & - & - & - & 10.62 & 15.94 \\
\hline Bioplex Manganese & - & - & - & - & - & - & 9.01 & 9.91 \\
\hline
\end{tabular}

(Chelates procured commercially from Alltech ${ }^{\mathrm{R}}$ ) 
external egg quality, egg weight and shape index was measured. The length and width of the eggs at the broadest points were measured with the help of a digital calliper (Mitutuyo, Japan). The shape index (SI) was calculated following the formula of Shultz (1953). To assess the internal quality of the egg, albumen index, yolk index, shell thickness, membrane thickness, shell, yolk and albumen percentage, Haugh unit, air cell and $\mathrm{pH}$ were measured following standard procedures. The method suggested by Heiman and Carver (1936) with slight modifications was adopted to determine albumen index (AI). The method of Sharp and Powell (1930) was used to determine the yolk index. Haugh unit (HU) was calculated by the formula of Haugh (1937).

The relative yolk weight, shell weight and albumen weight of the egg were measured using standard procedures. The shell thickness and membrane thickness of the egg were measured by digital gauge following standard procedure.The assessing of air cell was done as per the method outlined by Central Poultry Training Institute, Hessarghatta, Bangalore, India with some modification. After proper mixing of albumen and yolk, the $\mathrm{pH}$ of whole egg was estimated with the help of a digital $\mathrm{pH}$ meter (Systronic, Model No: 335)

The fertility of eggs was measured by candling method. The number of infertile eggs was recorded to estimate fertility percentage. For hatching, 20 eggs from each replicate were selected randomly from each replicate group.

The data were analysed by one-way analysis of variance (ANOVA) using SPSS (1997) to compare different parameters due to different treatments where the only source of variation is the type of mineral supplements. Duncan's test at $5 \%$ of significance was further followed to have group comparison between means of varying mineral types through homogenous subsets of such means.

\section{RESULTS}

The effects of different levels and forms of $\mathrm{Zn}$ and $\mathrm{Mn}$ on the general performance of layer chickens (21wk to $42 \mathrm{wk}$ ) are presented in Table 3 . The average gain in body weight $(\mathrm{g})$ was $496.88 \pm 3.39,552.12 \pm 1.39,603.21 \pm 1.58$ and $650.31 \pm 2.60$ respectively. The percentage of egg production was significantly higher $(\mathrm{P}<0.05)$ in the TOC group over the CTR group. Total number of eggs produced was also higher $(\mathrm{P}<0.05)$ in the TOC group $(1211.33 \pm 31.18)$ in comparison to the CTR group $(1008.00 \pm 35.81)$. Dry matter consumed $(\mathrm{g})$ per $\mathrm{kg}$ of egg was $2897.18 \pm 94.42,2762.00 \pm 82.10$, $2560.53 \pm 73.30$ and $2308.58 \pm 75.96$ respectively, and it was significantly lower $(\mathrm{P}<0.05)$ in both chelate supplemented groups. Calculated FCR for egg production was 2.89, $2.76,2.56$ and 2.30 respectively. Effects on egg quality and reproduction performance of layer chickens are presented in Table 4 . The average weight (g) of eggs was 55.70 \pm 0.17 , $55.92 \pm 0.13,57.94 \pm 0.09$ and $58.91 \pm 0.09$ in CTR, TMZ, TIC and TOC groups respectively. Both TIC and TOC groups significantly $(\mathrm{P}<0.01)$ varied from both $\mathrm{CTR}$ and TMZ groups, and there was a significant $(\mathrm{P}<0.01)$ difference between TIC and TOC groups but no significant difference was found between CTR and TMZ groups. Statistical analysis revealed that shape index in TIC $(74.59 \pm 0.26)$ and TOC $(75.96 \pm 0.18)$ groups were significantly higher $(\mathrm{P}<0.01)$ than $\mathrm{CTR}$ $(70.71 \pm 0.44)$ and TMZ (71.23 \pm 0.31$)$ groups. However, TOC groups differed significantly from the TIC group, and there was no significant difference between CTR and TMZ groups. Data on average albumen index was significantly $(\mathrm{P}<0.01)$ varied among the groups, which showed a similar trend of increasing shape index in CTR, TMZ, TIC and TOC groups. The average yolk index was highest in the TOC group $(0.51 \pm 0.01)$. A significant difference $(\mathrm{P}<0.01)$ was observed among the experimental groups showing a gradual increase of yolk index in CTR, TMZ, TIC and TOC groups in a similar manner of shape index values. The average shell thickness $(\mathrm{mm})$ value in TOC $(0.45 \pm 0.02)$ group was significantly $(\mathrm{P}<0.05)$ higher than CTR $(0.38 \pm 0.02)$ and 
Table 3. Effect of various forms and levels of zinc and manganese on general performance of RIR layer chickens ( 21 to 42 wks of age)

\begin{tabular}{lllllc}
\hline \multicolumn{1}{c}{ Particulars } & CTR & TMZ & TIC & TOC & $\begin{array}{c}\text { Level of } \\
\text { significance }\end{array}$ \\
\hline Initial body weight $(\mathrm{g})$ & 1504.18 & 1498.18 & 1497.83 & 1499.78 & NS \\
& \pm 4.29 & \pm 3.55 & \pm 4.35 & \pm 2.27 & \\
Final body weight $(\mathrm{g})$ & $2001.05^{\mathrm{d}}$ & $2050.30^{\mathrm{c}}$ & $2101.04^{\mathrm{b}}$ & $2150.09^{\mathrm{a}}$ & $* *$ \\
& \pm 1.44 & \pm 2.60 & \pm 2.78 & \pm 1.93 & \\
Average gain in body weight $(\mathrm{g})$ & $496.88^{\mathrm{d}}$ & $552.12^{\mathrm{c}}$ & $603.21^{\mathrm{b}}$ & $650.31^{\mathrm{a}}$ & $* *$ \\
& \pm 3.39 & \pm 1.39 & \pm 1.58 & \pm 2.60 & \\
Dry matter consumed per bird (g) & 18022.53 & 18126.15 & 18239.44 & 18331.69 & NS \\
& \pm 114.49 & \pm 114.47 & \pm 148.89 & \pm 199.19 & \\
Dry matter intake/bird/day (g) & $104.03^{\mathrm{c}}$ & $105.84^{\mathrm{bc}}$ & $108.22^{\mathrm{b}}$ & $113.18^{\mathrm{a}}$ & $* *$ \\
& \pm 0.63 & \pm 0.77 & \pm 0.82 & \pm 1.03 & \\
Percentage of egg production $(\%)$ & $72.73^{\mathrm{b}}$ & $76.36^{\mathrm{b}}$ & $80.04^{\mathrm{ab}}$ & $87.40^{\mathrm{a}}$ & $*$ \\
& \pm 2.58 & \pm 2.65 & \pm 2.54 & \pm 2.25 & \\
Total number of eggs (nos.) & $1008.00^{\mathrm{b}}$ & $1058.33^{\mathrm{b}}$ & $1109.33^{\mathrm{ab}}$ & $1211.33^{\mathrm{a}}$ & $*$ \\
& \pm 35.81 & \pm 36.71 & \pm 35.22 & \pm 31.18 & \\
Dry matter consumed per kg & $2897.18^{\mathrm{a}}$ & $2762.00^{\mathrm{a}}$ & $2560.53^{\mathrm{bc}}$ & $2308.58^{\mathrm{c}}$ & $*$ \\
of eggs (g) & \pm 94.42 & \pm 82.10 & \pm 73.30 & \pm 75.96 & \\
First laying age (days) & $134.00^{\mathrm{a}}$ & $134.00^{\mathrm{a}}$ & $132.00^{\mathrm{b}}$ & $130.00^{\mathrm{c}}$ & $* *$ \\
& \pm 0.58 & \pm 0.58 & \pm 0.58 & \pm 0.58 & \\
\hline
\end{tabular}

Means bearing different superscripts in the same row differ significantly $(* \mathrm{P}<0.05 ; * * \mathrm{P}<0.01 ;$ NS- Non significant)

Table 4. Effect of various forms and levels of zinc and manganese on the egg quality and reproductive parameters in $\mathrm{RIR}$ layer chickens ( 21 to 42 wks of age)

\begin{tabular}{llcccc}
\hline Particulars & \multicolumn{1}{c}{ CTR } & TMZ & TIC & TOC & $\begin{array}{c}\text { Level of } \\
\text { significance }\end{array}$ \\
\hline Weight of egg $(\mathrm{g})$ & $55.70^{\mathrm{c}} \pm 0.17$ & $55.92^{\mathrm{c}} \pm 0.13$ & $57.94^{\mathrm{b}} \pm 0.09$ & $58.91^{\mathrm{a}} \pm 0.09$ & $* *$ \\
Shape Index & $70.71^{\mathrm{c}} \pm 0.44$ & $71.23^{\mathrm{c}} \pm 0.31$ & $74.59^{\mathrm{b}} \pm 0.26$ & $75.96^{\mathrm{a}} \pm 0.18$ & $* *$ \\
Albumen Index & $0.10^{\mathrm{c}} \pm 0.00$ & $0.11^{\mathrm{c}} \pm 0.00$ & $0.14^{\mathrm{b}} \pm 0.00$ & $0.15^{\mathrm{a}} \pm 0.00$ & $* *$ \\
Yolk Index & $0.44^{\mathrm{c}} \pm 0.01$ & $0.45^{\mathrm{c}} \pm 0.00$ & $0.48^{\mathrm{b}} \pm 0.00$ & $0.51^{\mathrm{a}} \pm 0.01$ & $* *$ \\
Shell thickness (mm) & $0.38^{\mathrm{c}} \pm 0.02$ & $0.39^{\mathrm{bc}} \pm 0.02$ & $0.42^{\mathrm{ab}} \pm 0.02$ & $0.45^{\mathrm{a}} \pm 0.02$ & $*$ \\
Membrane thickness (mm) & $0.07 \pm 0.00$ & $0.08 \pm 0.00$ & $0.08 \pm 0.00$ & $0.09 \pm 0.00$ & $\mathrm{NS}$ \\
Shell \% & $10.34 \pm 0.13$ & $10.50 \pm 0.15$ & $10.56 \pm 0.14$ & $10.66 \pm 0.16$ & $\mathrm{NS}$ \\
Yolk \% & $27.17 \pm 0.12$ & $27.21 \pm 0.26$ & $27.19 \pm 0.40$ & $27.26 \pm 0.14$ & $\mathrm{NS}$ \\
Albumen \% & $62.49 \pm 0.25$ & $62.29 \pm 0.41$ & $62.25 \pm 0.26$ & $62.08 \pm 0.31$ & $\mathrm{NS}$ \\
Haugh Unit & $87.57^{\mathrm{c}} \pm 0.43$ & $87.84^{\mathrm{c}} \pm 0.79$ & $89.92^{\mathrm{b}} \pm 0.45$ & $91.95^{\mathrm{a}} \pm 0.65$ & $* *$ \\
Air cell (mm) & $1.00 \pm 0.00$ & $1.00 \pm 0.00$ & $1.00 \pm 0.00$ & $1.00 \pm 0.00$ & $\mathrm{NS}$ \\
pH & $7.02 \pm 0.03$ & $6.99 \pm 0.03$ & $7.01 \pm 0.02$ & $7.01 \pm 0.04$ & $\mathrm{NS}$ \\
Fertility \% & $81.67 \pm 1.67$ & $86.67 \pm 3.33$ & $91.67 \pm 4.41$ & $96.67 \pm 3.33$ & $\mathrm{NS}$ \\
Hatchability \% & $80.00^{\mathrm{b}} \pm 2.89$ & $83.33^{\mathrm{b}} \pm 1.67$ & $88.33^{\mathrm{ab}} \pm 4.41$ & $95.00^{\mathrm{a}} \pm 2.89$ & $*$ \\
\hline Means bearing different superscripts in the same row differ significantly. $(* \mathrm{P}<0.05 ; * * \mathrm{P}<0.01 ; \mathrm{NS}-$ Non significant
\end{tabular}


TMZ $(0.39 \pm 0.02)$ groups, but there was no significant difference between TIC $(0.42 \pm 0.02)$ and TOC groups, though TIC group differ significantly only from CTR group. No significant difference was observed in membrane thickness, shell, yolk and albumen percentage, air cell and $\mathrm{pH}$ of the egg content. The average Hough unit was found to be $87.57 \pm 0.43,87.84 \pm 0.79,89.92 \pm 0.45$ and $91.95 \pm 0.66$ in CTR, TMZ, TIC and TOC groups respectively. Results revealed a significantly $(\mathrm{P}<0.01)$ higher value in TOC and TIC groups.

There was no significant difference observed in fertility percentage.The average percentage of hatchability of eggs was $80.00 \pm 2.89,83.33 \pm 1.67,83.33 \pm 4.41$ and $95.00 \pm 2.89$ in CTR, TMZ, TIC and TOC groups respectively. Analysis showed a significant $(\mathrm{P}<0.05)$ difference between TOC, and CTR and TMZ group, though no significant difference was observed between TIC and TOC groups.

\section{DISCUSSION}

Considering the role of $\mathrm{Zn}$ and $\mathrm{Mn}$ supplementation on production and reproduction performance of laying hen, particularly on egg quality, fertility and hatchability, present study was carried out to evaluate the efficacy of different forms and combination of $\mathrm{Zn}$ and $\mathrm{Mn}$ and the findings of this study do agree with others workers (Darvishi et al., 2020; Min et al., 2018). Increased body weight gain might be due to more feed consumption, more nitrogen retention and organic matter retention. Growth retardation is universally observed in $\mathrm{Zn}$ and Mn deficiency. Increased body weight gain is in agreement with the works of other researchers (Rutz et al., 2003; Min et al., 2018; Darvishi et al., 2020). Improved feed efficiency in terms of dry matter consumed per kg of eggs in chelate supplemented groups was also reported by Darvishi et al. (2020). FCR for egg production ( $\mathrm{kg}$ feed $/ \mathrm{kg}$ egg mass) in this study were within range (2.1 to 3.4 ) as reported by other workers in RIR (Khatun et al., 2005;
Akhtar et al., 2007). Significantly higher egg production percentage was observed in case of the TOC group. In a study in RIR conducted from 28 to 45 wks of age, egg production percentage was reported as $79 \%$ in the control group (Khatun et al., 2005). However, in the present study, the egg production percentage values were comparatively higher in all the experimental groups as the experimental period was considered only 22 weeks (i.e. $21 \mathrm{wk}$ to $42 \mathrm{wk}$ ). Significantly higher egg weight was recorded in TIC and TOC groups, and ascending order of values of average egg weight in CTR, TMZ, TIC and TOC groups was noticed. Siske et al. (2000) reported that 20\%, $40 \%$, and $50 \%$ substitution of inorganic minerals with organic forms including Bioplex ${ }^{\mathrm{TM}} \mathrm{Mn}$ improved egg production. The present study showed that the average Hough unit was significantly higher in chelate supplemented groups than the conventional inorganic source of $\mathrm{Zn}$ and $\mathrm{Mn}$ supplemented groups. The shape index was also significantly higher in the TOC group in present study. The present finding related to shell thickness was in closer agreement with the findings of Sazzad et al. (1994), Rapp et al. (2002) and Swiatkiewicz and Koreleski (2008). The increase in shell thickness might be due to an increase in carbonic anhydrase and alkaline phosphatase activity. $\mathrm{Zn}$ being a co-factor of this enzyme makes both activity and proper function of this enzyme potentially sensitive to trace elements, their interaction and availability. The presence of $\mathrm{Mn}$ has an activating effect on alkaline phosphatase, explaining the importance of these elements in the proper formation of eggshell. Ochrimenko et al. (1992) noted a positive effect of Mn supplements on calcification and eggshell strength. Though statistical analysis did not find any significant difference among the groups for average shell percentage, an ascending value was obtained, reflecting ascending increment in shell weight along with an increase in egg weight. The present finding related to shell, yolk and albumen percentage was in close agreement with the findings of Rapp et al. (2002) and Rutz 
et al. (2003). The Haugh unit value is used to assess the egg protein quality based on the height of its egg white (albumen). The average $\mathrm{HU}$ in the TOC group was significantly higher than the other groups, and HU in the TIC group was significantly higher than the HU values of both CTR and TMZ groups but significantly lower than the TOC group, although no significant difference was observed between CTR and TMZ groups. Overall an ascending value of HU was observed in CTR, TMZ, TIC and TOC groups in the present study reflecting good quality of eggs in case of supplementation of $\mathrm{Zn}$ and $\mathrm{Mn}$ in chelated form. Though some studies found no significant variation in the Hough unit (Yenice et al., 2015; Zapata, 2016; Darvishi et al., 2020), some other studies reported a similar trend of present findings (Idowu et al., 2011; Abd et al., 2018). Nonsignificant improvement in fertility and significant improvement in hatchability in chelate form of $\mathrm{Zn}$ and $\mathrm{Mn}$ supplemented groups is in agreement with other published

\section{REFERENCES}

Abd El-Hack ME, Alagawany M, Amer SA, Arif M, Wahdan KMM et al., 2018. Effect of dietary supplementation of organic zinc on laying performance, egg quality and some biochemical parameters of laying hens. J Anim Physiol Anim Nutr (Berl), 102(2): 542-549, doi: 10.1111/jpn.12793

Akhtar N, Mahmood S, Hassan M and Yasmeen F, 2007. Comparative study of production potential and egg characteristics of Lyallpur Silver Black, Fayoumi and Rhode Island Red breeds of poultry. Pakistan Vet J, 27(4): 184-188

AOAC, 1970. Official Methods of Analysis, $11^{\text {th }}$ edn. Association of Official Analytical Chemists, Washington DC

BIS (1992). Nutrient REQUiREMENTS fOr POULTRY. IS:13574:1992

Dobrzanski ZD, Jamroz H, Gorecka H and Opalinski S, 2003. Bioavailability of selenium and zinc supplied to the feed for laying hens in organic and inorganic forms. Electronic J Polish Agri Univ, 6(2): art-03

Darvishi Y, Shams Shargh M and Hassani S, 2020. Effect of organic or inorganic zinc and manganese sources on performance and egg quality traits of laying hens. J Adv Pharm Edu Res, 10(S1): 22-28 work (Yenice et al., 2015). Siske et al. (2000) observed increase fertilization of hatching eggs in cockerels substituting $50 \%$ of the inorganic $\mathrm{Zn}, \mathrm{Mn}$ and Se with organic chelates. The present finding was supported by Rutz et al. (2003), who observed $3.4 \%$ increases in hatchability in the organic mineral supplemented group than the control group.

The present study revealed that supplementation of chelated $\mathrm{Zn}$ and $\mathrm{Mn}$ improved egg weight, feed efficiency, first laying age, egg quality (egg weight, shape index, albumen index, yolk index, shell membrane thickness, Haugh unit) and hatchabilityas compared to inorganic sources in RIR layer chickens. Therefore, it can be concluded that chelated $\mathrm{Zn}$ and Mn may improve overall productive performance, egg quality and hatchability in layer chickens.

Conflict of interest: Authors have no conflict of interest in this study.

Favero A, Viera SL, Angel CR, Bos-Mikich A, Lothammer N et al., 2013. Development of bone in chick embryos from Cobb 500 breeder hens fed diets supplemented with zinc, manganese, and copper from inorganic and amino acid complexed sources. Poult Sci, 92(2): 402-411, doi: 10.3382/ ps.2012-02670

Gheisari AA, Sanei A, Samie A, Gheisari MM and Toghyani M, 2011. Effect of diets supplemented with different levels of manganese, zinc, and copper from their organic or inorganic sources on egg production and quality characteristics in laying hens. Biol Trace Elem Res, 142(3): 557-571, doi: 0.1007/s12011-010-8779-X

Hafeez A, 2015. Effect of different feed treatment strategies on apparent mineral digestibility and retention in broilers and layers and egg quality in laying hens. Freie Univ Berlin, doi: 10.17169/refubium-12211

Haugh RR, 1937. The Haugh unit for measuring egg quality. US Egg Poult Mag, 34: 552-555

Heiman V and Carver JS, 1936. The albumen index as a physical measurement of observed egg quality. Poult Sci, 15(2): 141-148, doi: 10.3382/ps.0150141 Idowu OMO, Ajuwon RO, Oso AO and Akinloye OA, 
2011. Effects of zinc supplementation on laying performance, serum chemistry and zn residue in tibia bone, liver, excreta and egg shell of laying hens. Int J Poult Sci, 10: 225-230, doi: 10.3923/ ijps.2011.225.230

Khatun R, Azmal SA, Sarker MSK, Rashid MA, Hussain MA et al., 2005. Effect of silkworm pupae on the growth and egg production performance of Rhode Island Red (RIR) pure line. Int J Poult Sci, 4(9): 718-720

Leeson S and Summers JD, 2009. Commercial Poultry Nutrition, $3^{\text {rd }}$ edn. (Ontario, Canada, University Books), pp 198

Mabe I, Rapp C, Bain MM and Nys Y, 2003. Supplementation of a corn-soybean meal diet with manganese, copper, and zinc from organic or inorganic sources improves eggshell quality in aged laying hens. Poult Sci, 82(12): 1903-1913, doi: $10.1093 / \mathrm{ps} / 82.12 .1903$

Min YN, Liu FX, Qi X, Ji S, Ma SX et al., 2018. Effects of methionine hydroxyl analog chelated zinc on laying performance, eggshell quality, eggshell mineral deposition, and activities of $\mathrm{Zn}$-containing enzymes in aged laying hens. Poult Sci, 97: 35873593, doi: $10.3382 /$ ps/pey203

Ochrimenko C, Lemser A, Richter G, Krause U and Bonsak H, 1992. Effect of manganese content in laying hen fed with different calcium and mineral levels on the eggshell quality and bone mineralization of hens. Arch Tierernahr, 42(1): 2535, doi: 10.1080/17450399209428526

Rapp CJ, Ward TLand Flaker TM, 2002. Trace minerals in table egg layer nutrition. Int Poult Prod, 10(6): 3335

Rutz F, Ederson AP, Guilherme BX and Marcos AA, 2003. Sel-PlexTM and Bio-PlexTM trace minerals in commercial broiler and breeder diets. In: Nutritional Biotechnology in the Feed and Food Industries, Proceedings of All Tech's $19^{\text {th }}$ Annual Symposium (eds. T.P. Lyons and K.A. Jacques), Nottingham University Press, Nottingham, UK, pp 155-159

Sazzad HM, Bertechini AG and Nobre OTC, 1994. Egg production, tissue deposition and mineral metabolism in two strains of commercial layers with various levels of manganese in diet. Anim Feed Sci Tech, 46(3-4): 271-275, doi: 10.1016/0377-8401(94)90145-7

Sharp PF and Powell CK, 1930. Decrease in internal quality of hen's eggs during storages as indicated by the yolk. Ind Eng Chem, 22(8): 208-910, doi: 10.1021/ie50248a031

Shultz FT, 1953. An analysis of egg shape of chicken. Biometrics, 9(3): 336-353, doi: 10.2307/3001710

Siske V, Zeman L and Klecker D, 2000. The eggshell: A case study in improving quality by altering mineral metabolism naturally. Bio technol Feed Industry, 16: 327-346

SPSS Inc, 1997. SPSS Base 7.5 for Windows User's Guide. Prentice Hall

Swiatkiewicz S and Koreleski J, 2008. The effect of zinc and manganese source in the diet for laying hens on eggshell and bones quality. Veterinarni Medicina, 53(10): 555-563

Yenice E, Mizrak C, Gültekin M, Atik Z and Tunca M, 2015. Effects of dietary organic or inorganic manganese, zinc, copper and chrome supplementation on the performance, egg quality and hatching characteristics of laying breeder hens. Ankara Univ Vet Fak Derg, 62: 63-68, doi: 10.1501/Vetfak 0000002658

YildizAO, Cufadar Y and Olgun O, 2011. Effects of dietary organic and inorganic manganese supplementation on performance, egg quality and bone mineralisation in laying hens. Review Med Vet, 162(10): 482-488

Zamani A, Rahman HR and Pourrez J, 2005. Supplementation of a corn-soybean meal with manganese and zinc improves eggshell quality in laying hens. Pakistan J Biol Sci, 8(9): 1311-1317, doi: 10.3923/pjbs.2005.1311.1317

Zapata NKR, 2016. Effect of increasing levels of dietary zinc $(\mathrm{Zn})$, manganese $(\mathrm{Mn})$, and copper $(\mathrm{Cu})$ from organic and inorganic sources on egg quality and egg $\mathrm{Zn}, \mathrm{Mn}$, and $\mathrm{Cu}$ content in laying hens. A thesis of Master of Science. Faculty of the Louisiana State Univ and Agri Mech College 